Perspective Article

\title{
The Death of the Public Community College
}

\author{
William E. Piland (Corresponding author) \\ Professor Emeritus, San Diego State University \\ 5500 Campanile Drive, San Diego, CA 92182, USA \\ E-mail: piland1@mail.sdsu.edu
}

Received: September 5, 2016 Accepted: October 16, $2016 \quad$ Published: October 25, 2016

doi:10.5296/jei.v2i2.9988 URL: http://dx.doi.org/10.5296/jei.v2i2.9988

\begin{abstract}
Community colleges have been in existence for over 100 years in the United States. They began by offering the first two years of undergraduate education for students in local communities. Over the decades they evolved into comprehensive institutions of higher education with a multi-faceted mission. Today, in an era of accountability and mistrust of governmental institutions, they are under siege. There are external and internal forces that are causing their troubles. Perhaps, the unthinkable could happen and they might cease to exist if bold steps aren't taken to save them. There appears to be little time to waste.
\end{abstract}

Keywords: Community colleges, External and internal factors, Death, Student success

\section{Obituary}

The last public community college in America ceased operations at 11:59 pm on June 30, 2022. The death was long, slow and agonizing. What began as a noble American higher education experiment in the Mid-west came to an inglorious end. While the "peoples college" impacted millions and millions of Americans, its passing was not universally mourned. The cause of death was listed as "starvation." The colleges literarily were starved of resources.

\section{External Contributors to Death}

The usual suspects of sociological, economical, and political factors were listed as contributors to the death of community colleges. Like insidious, chronic diseases, these factors didn't flare up over night. Rather they developed over some decades. However, events in the last decade and a half accelerated the colleges' demise. 
During the 1970s a strong anti-tax movement began to grow in the country. Forces coalesced around this anti-tax movement that began in California with Prop 13 that limited the ability of governmental agencies, including community colleges, to raise local property taxes, and moved throughout the country. This phenomenon began at the local level and spread to the states like wildfire and eventually became pronounced at the federal level. Regardless of the reason for a tax increase, the response was always the same-NO MORE TAXES! Politicians became embroiled in the movement and eventually came to lead it. They began to sign "no tax pledges" to stand fast against any increase in public revenues.

This anti-tax movement eventually morphed into an irrational, visceral hatred of government at all levels. The public sector was deemed to be inefficient, bloated and inept. A libertarian philosophy of small government with few resources became rooted in the American consciousness. The disciples of this philosophy wanted to starve government and move time honored governmental functions to the private sector, where efficiency, performance and cost savings reigned supreme. Once again, politicians lubricated with campaign contributions from wealthy individuals, corporations and associations representing private sector interests led the charge and railed against government ineptitude. The people behind this shift in the public attitude about the role of government in society had strong value systems tied to private enterprise and capitalism and many saw an opportunity to profit from the privatization of governmental functions.

The benefits provided to public sector employees became a flash point for the movement. Generous defined benefits retirement plans, free or inexpensive health insurance, long vacation periods, and an unreasonable protection from being fired were all viewed as excessive and an example of government waste at the tax- payers expense. People compared these benefits to counterparts in the private sector and said "Enough!"

Community colleges, as governmental entities, were painted with the same broad brush applied to other public sector organizations. Whatever these colleges were doing could be done better and cheaper by the private sector, and that included educating the people of the country. When politicians, professional rabble rousers, and the public became aware of the poor performance of their local community colleges on a number of measures that made sense to them (graduation rates, time to graduation, transfer rates, student performance as measured by grades, and persistence in the college) they saw a huge opening. Policy makers and politicians extended the negative connotations of "government work" to community colleges. These actions set the stage for the slow but steady decline of resources for community colleges.

Similarly, the mania to privatize government functions began to explode in higher education. For-profit-colleges and proprietary schools made substantial inroads in what was historically the student market for local community colleges. Even though these institutions charged substantially higher tuition than community colleges, because of generous financial aid packages, flexible schedules and lax rules and regulations, and aggressive marketing and recruitment campaigns these institutions made drastic cuts into the market share of community colleges. They fit right in with the run to the alter of private enterprise and the 
corporations and wealthy individuals who owned these colleges and schools made substantial political contributions to politicians who carried their water at local, state and national governmental levels. The deck truly was stacked against public community colleges.

The playing field for community colleges became so uneven that they could no longer compete with the forces aligned against them. Community colleges served the interests and needs of the powerless in society. There was no one to make large campaign contributions on their behalf, no one to make the case against the social Darwinism that was sweeping the land, no one to confront the privileged from denigrating the less privileged, and no one to speak for low income, communities of color in the halls of power.

\section{Internal Contributors to Death}

The demise of community colleges did not occur solely because of external forces. The colleges contributed to their own downfall. When the policy makers and the public demand results, the colleges provided excuses. When transformational change was required, they defended the status quo or introduced change at a snail's pace. When a sense of urgency was required, they countered with complacency (Boggs \& McPhail, 2016). After all, the colleges had existed for over 100 years. They would go on forever, wouldn't they? The people in the local communities loved them, didn't they? Alas, the results proved otherwise.

The people who ran the colleges, from trustees to administrators to faculty refused to acknowledge the signs of decline. Trustees, whether elected or appointed, were too often beholden to the interests that put them into their positions, too often were concerned with minutia, too often interceded in the colleges' business on behalf of disgruntled community members, and were on the periphery of the real powerbrokers in the larger community. College administrators were consumed with fighting fires, usually blazes caused by personnel issues, constructed long-range plans but operated on an hour-by-hour basis, were too timid to introduce new ways of thinking or shaping the teaching and learning environment, and besieged by competing demands from faculty, students and their own professional advancement and development. Faculty blamed the students for poor performance or the feeder high schools that did not prepare them for college level work, resisted changes to their normal teaching routines, became obsessed with process over results, and retreated to the safe and scared grounds of their disciplines. Community college students were the most powerless to stop the assault on their education. Individually their voices were never heard and collectively their voices were ignored because, after all, they were here today but would be gone tomorrow, probably by dropping out, with a small number graduating or transferring.

The poor performance of community colleges across the land, with their abysmally low graduation and transfer rates, brought scrutiny to the colleges (Bailey, Jaggars, \& Jenkins, 2015; Bahr, Toth, Thiroff, \& Masse, 2013). Some organizations, entities and individuals tried to stem the tide of failure. Numerous foundations began shifting monies to community colleges, performance-based funding schemes with resources for top performing colleges began to sweep through the states, the federal government shown a spotlight on community colleges and launched a much ballyhooed graduation push, without money, of course. Innumerable initiatives such as Achieving the Dream, Completion by Design, Pathways to 
Completion, Complete College America, National Community College Benchmarking Project, American Diploma Project, and others did begin to move the needle of success, however imperceptibly. Many of these initiatives worked on the margins. Improvements were made, at a glacial pace. They were not enough to keep the critics at bay.

\section{Could the Community Colleges Have Been Saved?}

Perhaps. It would have taken a herculean effort by groups outside the colleges who supported local community colleges and by the people who worked in these colleges. The colleges needed to put student success at the forefront of all decisions made at all levels of the college, not just pay lip-service to the success agenda. Student success needed to permeate every committee, task force, and class of employees. Data informed decisions had to become the norm to the point that no committee meeting should have been held without people bringing data to the meeting.

Change needed to be radical and transformational. Every college policy, rule, procedure and practice needed to be scrutinized and reformed immediately if it provided a barrier to student success and completion (AACC, 2009). The teaching-learning environment had to be rebuilt to focus on research driven strategies that proved successful with students. Administrators, faculty and support staff who stood in the way of improvement or could not change their practices should have been given a short time to improve (one year maximum) or be dismissed. Trustees needed to demand accountability for student success from the entire college community with sanctions for people not delivering results.

Community college leaders and their friends and supporters at the local, state and national levels needed to mount a proactive campaign to save the colleges (Coley, 2000). They needed to bring together the powerful and the powerless to not only support but also demand the transformational changes needed by the colleges. Then they needed to proclaim the value of the colleges for, not only the "left outs" in society but the whole of society, including the upper and middle classes. They needed to confront head-on the criticisms leveled at the colleges and show through empirical data and anecdotal stories the impact of the colleges on economic development, reduced social costs, an educated and skilled workforce for the private sector, and the return on investment in the colleges by the public (Pilati, 2011).

Looking backwards from the year 2022, the task to save the colleges seems daunting. Yet, the demise of these colleges appears unthinkable. Will the obituary cited earlier be a foregone conclusion or will the people who really care about community colleges have the desire and wherewithal to save the colleges from a premature death? If action isn't taken NOW, the answer is, unfortunately, all too obvious.

\section{References}

AACC. (2014). Statement on Common Criticisms of Colleges-The Community College Perspective. American Association of Community Colleges, Washington: DC.

Bahr, P., Toth, C., Thirlof, K., \& Masse, J. (2014). A Review and Critique of the Literature on Community College Students' Transition Processes and Outcomes. Four-Year Institutions in 
Higher Education: Handbook of Theory and Research, 28, 459-511.

Bailey, T., Jaggars, S., \& Jenkins, D. (2015). Redesigning American community colleges: A clearer path to student success. Harvard University Press. Cambridge, MA.

Boggs, G. and McPhail, (2016). Practical leadership in community colleges: Navigating today's challenges. Jossey-Bass, Hobokem, NJ.

Coley, R. (2000). The American community college turns 100: A look at its students, programs and prospects. Educational Testing Service. Princeton, NJ.

Pilati, M. (March 2011), United we succeed: Responding to criticisms of the California Community Colleges. Academic Senate for California Community Colleges, Sacramento, CA.

\section{Copyright Disclaimer}

Copyright for this article is retained by the author(s), with first publication rights granted to the journal.

This is an open-access article distributed under the terms and conditions of the Creative Commons Attribution license (http://creativecommons.org/licenses/by/3.0/). 